\title{
Read Aloud Video Sebagai Media Pembelajaran Daring pada Masa Pandemi Covid-19 di TK Aisyiyah Sidoharjo - Wonogiri
}

\author{
Syifaul Fuada ${ }^{1 *}$, Marhamah ${ }^{2}$ iD \\ ${ }^{1,2}$ Universitas Pendidikan Indonesia, Indonesia \\ *Corresponding author: syifaulfuada@upi.edu
}

\section{Abstrak}

Saat pembelajaran daring dimasa pandemi Covid-19, guru harus mampu membuat media pembelajaran yang tepat agar siswa tetap mampu memiliki kompetensi ini dengan pendampingan orang tua siswa dirumah. Namun, berdasarkan observasi, guru di TK Aisyiyah, Sidoharjo, Wonogiri, Jawa Tengah menerapkan mekanisme pembelajaran yang masih monoton untuk semua materi, termasuk kompetensi penguasaan membaca siswa, yaitu sebatas penugasan di WhatsApp group dan tidak ada kegiatan home visit karena keadaan yang tidak mendukung. Tujuan dari kegiatan pengabdian kepada masyarakat ini adalah membantu guru untuk menyediakan sebuah media pembelajaran khusus untuk topik membaca melalui read aloud video yang diunggah Youtube. Dalam video, pelaksana meceritakan isi buku bergenre Fabel. Pembelajaran dilakukan oleh pelaksana sendiri dengan ijin guru kelas di WhatsApp group. Tautan video dibagikan kepada 10 orang tua siswa di WhatsApp Group kemudian siswa yang didampingi orang tuanya menyimak Read Aloud video. Siswa yang berhasil mengirimkan video tentang menceritakan kembali isi cerita di WhatsApp group, diberikan Reward berupa poster card. Hasil menunjukkan bahwa siswa menyukai video read aloud, membantu mengingkatkan konsentrasi dan pemahaman terhadap isi buku (dalam hal ini adalah cerita dalam read aloud video), kepercayaan diri, cara berkomunikasi lisan, dan mendorong motivasi siswa dalam belajar daring. Dengan read aloud video yang telah dibuat oleh pelaksana, guru dapat terbantu dalam menyiapkan media pembelajaran yang tepat sesuai topik atau kompetensi dasar. Lebih lanjut, pembelajaran daring di TK Aisyiyah dapat lebih bervariasi.

Kata Kunci: Pandemi Covid-19, Pembelajaran Daring, Read Aloud Video, YouTube

\section{Abstract}

During online learning, due to the Covid-19 pandemic, teachers should to create the right learning media; thus, the students still have this competency with the assistance of parents at home. However, based on observations, teachers at Aisyiyah Kindergarten apply a monotonous learning mechanism for all materials, including students' reading mastery competence, which was limited to assignments in WhatsApp messenger in a virtual class and no home visit activities due to unsupportive circumstances. This education-based community service aims to help teachers provide learning media for reading topics through read-aloud videos uploaded by Youtube. In this video, we told the contents of the Fable genre book. The learning process was carried out by ourselves with the class teacher's permission in the WhatsApp group. The video link of Youtube was shared with ten parents in the WhatsApp Group, then students, accompanied by their parents, listened to the Read Aloud video. Ten students who successfully sent videos about retelling the story's contents in the WhatsApp group will be given a poster card as a reward. The results showed that students liked to read aloud videos, helped increase concentration and understanding of the book's contents (in this case, the stories in a read-aloud video), selfconfidence, how to communicate verbally as well, and encouraged students' motivation in online learning. By using our read-aloud video, teachers can be helped to provide proper learning media to the children. Later, online learning at Aisyiyah Kindergarten can be more varied.

Keywords: The Covid-19 Pandemic, Online Learning, Read Aloud Video, YouTube

\section{INTRODUCTION}

Penyebaran virus covid-19 di Indonesia telah mempengaruhi berbagai aspek kehidupan manusia termasuk aspek pendidikan. Untuk meminimalisir proses penyebaran virus covid-19 di lingkup pendidikan pemerintah mengambil kebijakan untuk melaksanakan

$\begin{array}{ll}\text { History: } & \\ \text { Received } & \text { : April 03, } 2021 \\ \text { Revised } & \text { : April 09, } 2021 \\ \text { Accepted } & \text { : May 16, } 021 \\ \text { Published } & \text { : May 25, } 2021\end{array}$


pembelajaran secara daring (Majid et al., 2021). Pembelajaran secara daring dilakukan dengan memanfaatkan koneksi internet dengan menggunakan berbagai alat penunjang seperti smartphone, laptop atau televisi (Putria et al., 2020). Pelaksanaan pembelajaran secara daring dilakukan untuk memenuhi standard pendidikan di masa pandemi melalui pemanfaatan teknologi-teknologi sehingga guru dengan peserta didik tetap terhubung untuk melaksanakan pembelajaran walaupun "ruang" dan "waktu" tidak dalam satu kesatuan (Khusniyah \& Hakim, 2019; Suradika et al., 2020). Pembelajaran daring dapat memberikan pengalaman berlatih bagi peserta didik dengan adanya penggabungan kegiatan kolaboratif dengan belajar mandiri, umpan balik positif, dan personalisasi pembelajaran berdasarkan kebutuhan anak yang menggunakan simulasi dan permainan (Ayuni et al., 2020). Namun, pembelajaran daring di beberapa wilayah Indonesia tidak sepenuhnya berjalan mulus karena belum seluruhnya menerapkan teknologi dalam proses pembelajaran (Salam, 2021). Terdapat dua faktor penting dalam keberlangsungan pendidikan di Indonesia, yaitu belajar dan pembelajaran (Afandi et al., 2013; Fahyuni \& Nurdyansyah, 2016). Meskipun pandemi, belajar dan pembelajaran harus dijalankan dengan optimum.

Dampak Covid-19 telah dirasakan oleh guru dan siswa di sekolah-sekolah wilayah Wonogiri, Jawa Tengah. Untuk memutus rantai penyebaran Covid-19 di Wonogori, diterapkan physical distancing yang mengacu pada Instruksi Gubernur Jawa Tengah Nomor 1 Tahun 2020 tentang pembentukan "Satgas Jogo Tonggo" (Taruno et al., 2020). Sistem pembelajaran di seluruh jenjang Pendidikan di Wonogori tidak dapat dilaksanakan secara luring termasuk pada jenjang pendidikan usia dini. Masa usia dini merupakan salah fase anak yang juga perlu mendapatkan porsi perhatian (Nurhafizah, 2018), terutama di masa Pandemi. Melalui penyelenggaraan Pendidikan Anak Usia Dini (PAUD), pertumbuhan dan perkembangan anak secara menyeluruh dapat terfasilitasi (Suyadi, 2015). Selama pandemi, peran orang tua siswa PAUD sangat dibutuhkan dalam pembelajaran daring. Siswa belajar di rumah perlu memperoleh pendampingan dari orang tua atau orang dewasa untuk membantu memahamkan materi dari guru dan mengumpulkan tugas, meskipun dalam keseharian juga bekerja atau menjalani rutinitas hidup normal. Pekerjaan orang tua akan berat apabila guru hanya memberikan tugas saja, tanpa pendahuluan berupa materi yang memadahi (misalnya dalam bentuk video pembelajaran) dan tanpa kegiatan home visit dari guru pengampu. Pembelajaran daring untuk TK berbeda secara karakteristik dengan sekolah jenjang diatasnya, sehingga guru dan orang tua siswa harus berkolaborasi dengan memanfaatkan teknologi selama pandemi.

Berdasarkan observasi, guru, siswa, dan orang tua siswa di TK Aisyiyah, Sidoharjo, Wonogiri, Jawa Tengah merasakan berbagai kendala selama peralihan pembelajaran luring ke daring. Selain instruksi pemerintah setempat, pengubahan model daring ini distimulus oleh kejadian beberapa warga disekitar sekolah yang dinyatakan positif Covid-19. Kesiapan guru di TK Aisyiyah dalam menyiapkan media pembelajaran daring masih dikategorikan rendah karena tidak sepenuhnya menguasai aplikasi-aplikasi yang mendukung pembuatan media pembelajaran daring (misalnya kemampuan editing video, membuat video animasi, infografis interaktif, dan lain sebagainya), sehingga mekanisme penugasan terbatas pada pesan teks, pesan video, dan pesan suara di WhatsApp saja. Mayoritas guru dalam kategori senior. Minimnya penggunaan media pembelajaran menjadikan anak mudah bosan dan motivasi belajar anak cenderung menurun. Menurut penuturan guru, kemampuan membaca merupakan salah satu kompetensi yang harus dikuasai oleh siswa. Dan untuk memenuhi kompetensi ini kususnya pada pembelajaran daring maka guru membutuhkan suatu media yang mampu membantu guru untuk meningkatkan kemampuan membaca siswa. Salah satu media yang dapat membantu guru dalam mengajarkan materi membaca kepada siswa yakni media read aloud video. 
Read aloud merupakan kegiatan membaca dengan suara yang lantang dengan memperhatikan lafal dan intonasi sehingga dapat menarik perhatian siswa untuk menyimak sekaligus menumbuhkan minat baca (Priyantini \& Yusuf, 2020). Read aloud tidak hanya sekadar membaca dengan lantang, melainkan termasuk dalam unsur teatrikal ekspresi penuh sesuai dengan buku yang dibaca sehingga keinginan dalam diri anak untuk membaca, membangun literasi melalui bunyi, kemampuan mendengar, membaca, berbicara, dan menulis dapat tumbuh karena kemampuan penglihatan, pendengaran, dan ingatan anak juga turut aktif (Sumitra \& Sumini, 2019; Yumnah, 2017). Read aloud dapat membantu peserta didik memfokuskan perhatian secara mental, menimbulkan pertanyaan-pertanyaan, dan merangsang diskusi sehingga peserta didik dapat lebih fokus dalam mengikuti proses pembelajaran dengan dibantu oleh orang tua sebagai stimulus untuk meningkatkan pengetahuan serta kosa kata anak (Erik \& Cahyati, 2020; Panjaitan \& Hasanah, 2018).

Dalam proses pembelajaran daring media read aloud vidio sangatlah dibutuhkan guru untuk meningkatkan kemampuan membaca permulaan siswa. Hal ini sejalan dengan temuan pada penelitian (Harjanty, 2019) yang menunjukkan bahwa kegiatan membaca nyaring (read aloud) secara signifikan dapat meningkatkan kemampuan membaca permulaan siswa. Penelitian relevan selanjutnya yakni penelitian yang dilakukan oleh (Yumnah, 2017) yang menunjukkan bahwa penggunaan metode read aloud secara tidak langsung akan dapat membiasakan siswa untuk membaca dan meningkatkan kemampuan membaca siswa itu sendiri. Berdasarkan beberapa penelitian relevan diatas dapat diketahui bahwa read aloud akan mampu meningkatkan kemampuan membaca siswa serta membiasakan siswa untuk gemar membaca, dimana dalam proses pembelajaran daring membaca merupakan suatu hal yang harus dilaksanakan untuk meningkatkan kemampuan siswa serta memenuhi tujuan pembelajaran. Namun dalam penelitian sebelumnya belum terdapat penelitian mengenai implementasi read aloud vidio dalam pembelajaran. Tujuan dari penelitian ini adalah untuk membantu guru dalam melaksanakan pembelajaran daring anak usia dini di TK Aisyiyah Sidoharjo, Wonogiri, Jawa Tengah, kompetensi membaca nyaring melalui read aloud video.

\section{MATERIALS AND METHODS}

Penelitian pengabdian masyarakat ini dilaksanakan di TK Aisyiyah Sidoharjo, Wonogiri, Jawa Tengah dengan melibatkan 10 orang siswa. Pelaksanaan pembelajaran dengan menggunakan media vidio read aloud dilakukan dengan metode pembelajaran daring dengan memanfaatkan platform pembelajaran berupa whatsapp group dan youtobe. Kegiatan pembelajaran dilakukan dalam beberapa tahapan pelaksanaan yang terdiri dari tahap persiapan, pelaksanaan, dan tahap evaluasi dengan melakukan wawancara dengan orang tua siswa. Pada tahap persiapan, pelaksana melakukan perizinan secara daring di WhatsApp kepada salah satu guru di sekolah sasaran agar dapat melibatkan orang tua siswa dalam implementasi media pembelajaran daring "read aloud video", karena orang tua siswa adalah pendamping bagi anak-anaknya selama belajar dirumah. Pada tahap persiapan juga dilakukan proses penyusunan video pembelajaran dengan topik read aloud. Penyusunan serta pengeditan vidio dilakukan secara mandiri dengan menggunakan aplikasi Wondershare Filmora. Materi read aloud video diambil dari buku cerita anak inspiratif seri Fabel berjudul "Keserakahan Macan Tutul" yang ditulis oleh Filyan Alhazza. Setelah proses pengeditan selesai, video diunggah di YouTube. Pelaksana juga melakukan personal chat (Gambar 1b) dan voice call (Gambar 1c) kepada setiap orang tua untuk melakukan koordinasi. Pelaksana memberikan gambaran mengenai materi yang akan diberikan kepada siswa.

Setelah persiapan sudah cukup matang, proses pembelajaran dilanjutkan pada proses pelaksanaan yang dilakukan dengan mengirimkan link video YouTube ke whatsapp group. Orang tua yang mendampingi anak dapat mengakses dan menonton read aloud video 
bersama anak melalui YouTube tanpa harus bertemu secara langsung dengan pelaksana program. Waktu yang digunakan dalam implementasi read aloud video adalah dua jam untuk setiap pertemuan. Waktu dua jam tersebut dialokasikan untuk pembukaan di WhatsApp Group bersama dengan pengiriman link YouTube (30 menit), menyimak read aloud video dan mengerjakan tugas yang diberikan (1 jam), dan pengiriman dan perekapan tugas dari seluruh tugas siswa (30 menit). Tugas diberikan untuk mengukur hasil belajar siswa. Reward diberikan kepada semua siswa apabila tugas yang dikirimkannya telah sesuai dengan soal. Alokasi waktu 2 jam tersebut disesuaikan dengan situasi dan kondisi pembelajaran siswa di TK Aisyiyah, sehingga dapat berubah sewaktu-waktu. Tahap terakhir yakni tahap evaluasi dilakukan dengan melaksanakan wawancara kepada orang tua secara daring menggunakan WhatsApp personal chat dan voice call untuk mengetahui minat anak-anaknya dalam belajar daring setelah diberikan materi berupa video read aloud.

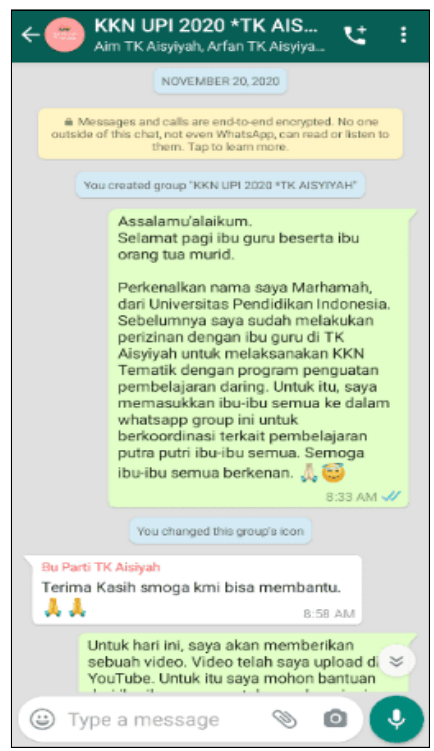

(a)



(b)

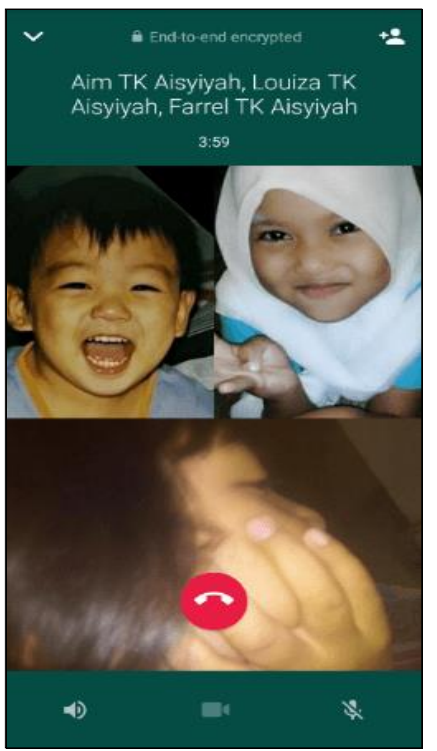

(c)

Gambar 1. Potongan koordinasi terhadap orang tua siswa di WhatsApp:

(a) Group; (b) Personal chat; (c) Voice call.

\section{RESULTS AND DISCUSSION}

\section{Hasil}

Hasil dari pelaksanaan kegiatan pengabdian masyarakat yang dilaksanakan di TK Aisyiyah Sidoharjo, Wonogiri, Jawa Tengah dapat dijabarkan sebagai berikut: Pertama, hasil dari koordinasi bersama guru dan orang tua siswa memutuskan bahwa pelaksanaan proses pembelajaran dilakukan dengan menggunakan platform whatsApp group dan youtobe. Setelah didapatkan kesepakatan mengenai platform yang akan digunakan kegiatan dilanjutkan dengan melakukan pencatatan nama siswa, nama orang tua, dan nomer whatsApp, untuk kemudian dibuatkan whatsApp group sebagai media untuk berkoordinasi dalam menunjang implementasi read aloud video (gambar 1a).

Kedua, pada tahap pelaksanaan pembelajaran media read aloud video diunggah pada channel youtobe "marhamah marhaman" seperti yang terlihat pada gambar 2. Pengaturan video di Youtube dipastikan agar dapat diakses secara publik. Berikutnya, pelaksana mengirim tautan read aloud video ke WhatsApp Group yang berisi guru dan orang tua siswa (Gambar 3b). Apabila anak telah menonton video tersebut, maka orang tua memberikan respon dengan menuliskan nama anaknya (Gambar 4). 

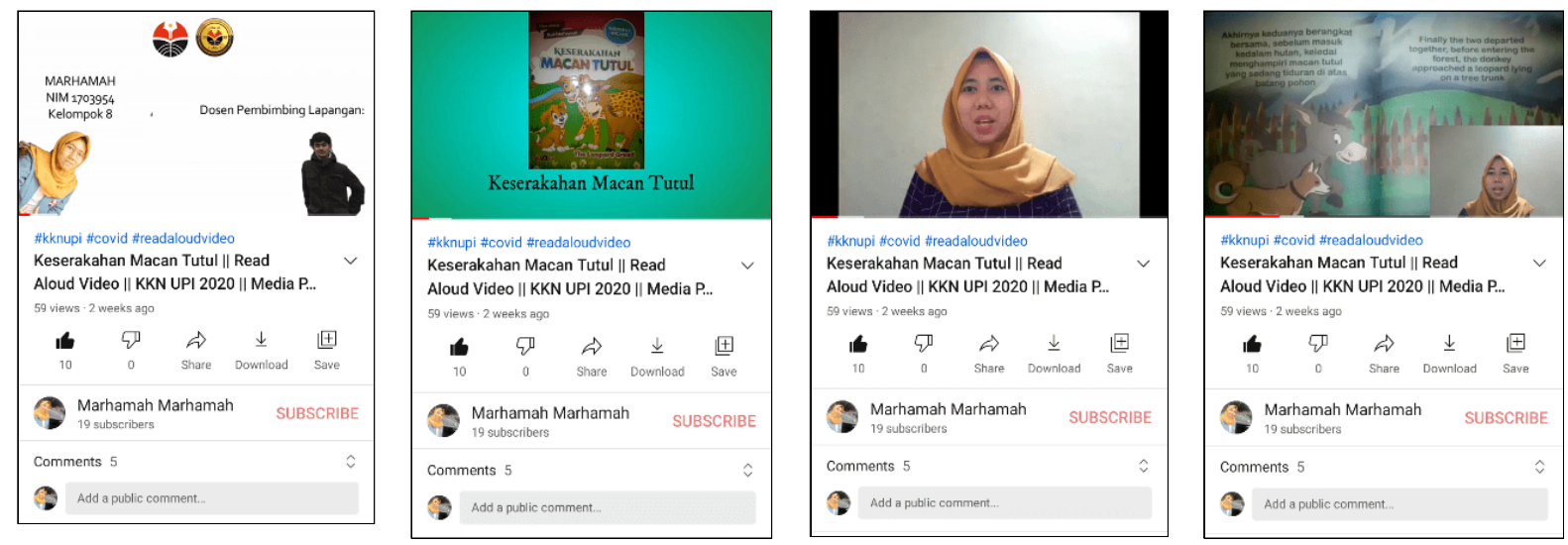

Gambar 2. Screen shoot media pembelajaran read aloud video di YouTube

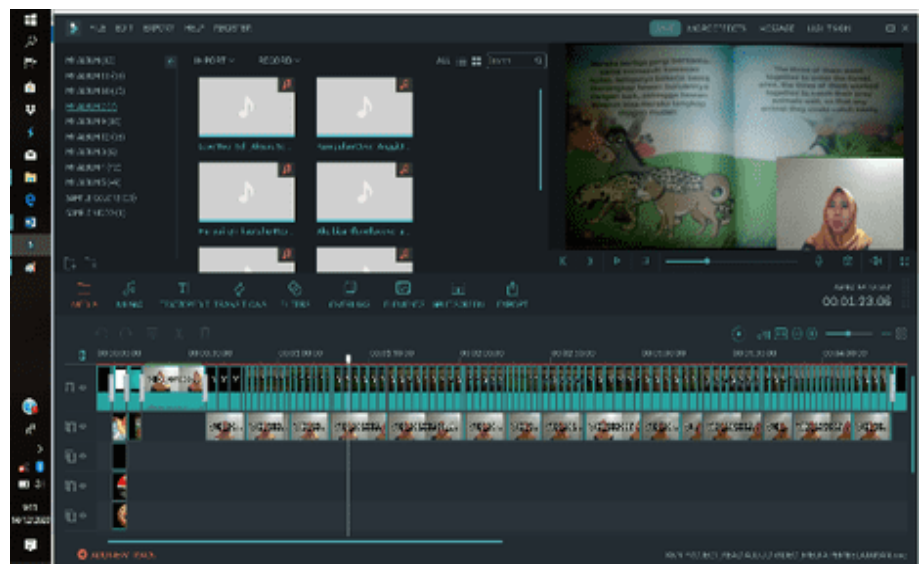

(a)

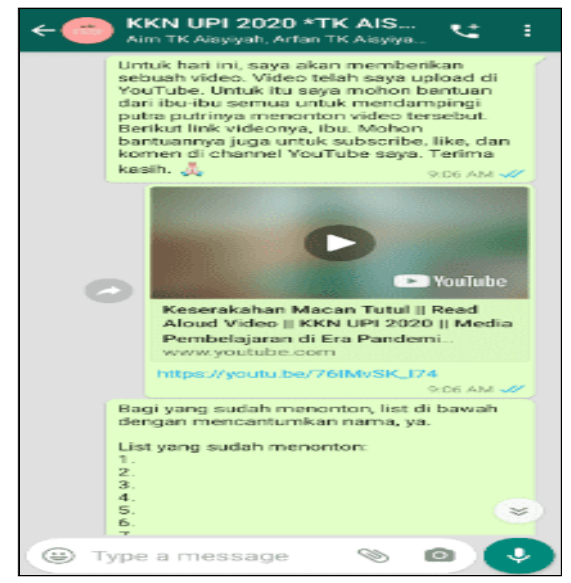

(b)

Gambar 3. (a) Screen shoot proses editing di aplikasi Wondershare Filmora;

(b) Pengiriman link video di WhatsApp Group kelas

Pelaksana pembelajaran menggunakan read aloud video dilakukan dengan pendampingan orang tua untuk mempermudah anak dalam memahami isi dari bacaan yang disajikan. Saat menyimak, orang tua sembari bercakap-cakap dengan anak terkait dengan materi dalam video tersebut. Kemudian, orang tua bersama dengan anak dapat mengulas kembali materi yang disampaikan melalui read aloud video tersebut setelah selesai menyimak video. Selanjutnya, pelaksana memberikan beberapa pertanyaan terkait materi dalam read aloud video. Siswa diharuskan menjawab pertanyaan tersebut melalui jawaban dalam bentuk tekstual, video, atau audio di WhatsApp Group (Gambar 5). Melalui penugasan ini, pelaksana dapat mengidentifikasi kemampuan setiap anak dalam aspek perkembangan bahasa, yaitu membaca, menulis, dan berbicara. Penugasan adalah satu ciri khas pembelajaran daring anak usia dini. Siswa mendapatkan reward setelah mengerjakan tugas yang diberikan yang berupa poster sederhana berisikan foto siswa (Gambar 6). Reward dibuat menggunakan Canva, yaitu Open-source Web tool yang menyediakan beragam template desain grafis (Lusiana et al., 2021). Pemberian reward dapat membantu meningkatkan semangat atau motivasi belajar siswa dalam mengikuti pembelajaran daring. Ketiga, tahap evaluasi dilakukan melalui proses wawancara dengan 8 dari 10 orang tua siswa di TK Aisyiyah Sidoharjo, Wonogiri, Jawa Tengah terkait dengan media pembelajaran read aloud video. Wawancara dilakukan di WhatsApp personal chat masing-masing orang tua siswa setelah penutupan kelas daring, dengan hasil sebagai berikut: 
"Videonya menarik, anak menjadi bersemangat untuk belajar dan sedikit-sedikit berani mengeskpresikan diri. Meskipun agak memaksa, hehe." (Orang tua siswa 1)

"Gambarnya dapat bergerak, bagus. Anak biasanya tidak mau diajak belajar, sekarang menjadi mau belajar karena baginya adalah hal yang menarik. Anak jadi sedikit percaya diri mengungkap cerita kembali" (Orang tua siswa 2)

"Videonya menarik, anak tidak bosan seperti pembelajaran sebelum-sebelumnya." (Orang tua siswa 3)

"Suaranya yang baca keras, anak ikut menirukan. Videonya juga bagus mudah dipahami alurnya." (Orang tua siswa 4)

"Anak senang melihat video ini. Isi videonya juga menarik sesuai tema di TK." (Orang tua siswa 5)

"Cara bacanya unik. Gambarnya bergerak, anak suka dan tidak menolak ketika diajak belajar." (Orang tua siswa 6)

"Videonya bagus. Isi ceritanya tidak rumit, anak mudah paham." (Orang tua siswa 7)

"Videonya sesuai untuk anak TK. Bagus, anak tidak bosan menyimak ceritanya." (Orang tua siswa 8)

Berdasarkan kutipan hasil wawancara dapat diketahui bahwa proses pembelajaran real aloud video dapat berjalan dengan baik, sesuai dengan arahan pelaksana dan bimbingan dari orang tua. Untuk meningkatkan semangat siswa dalam belajar kegiatan evaluasi dilanjutkan dengan pemberian reward kepada para siswa sebagai betuk motivasi dan dorongan.
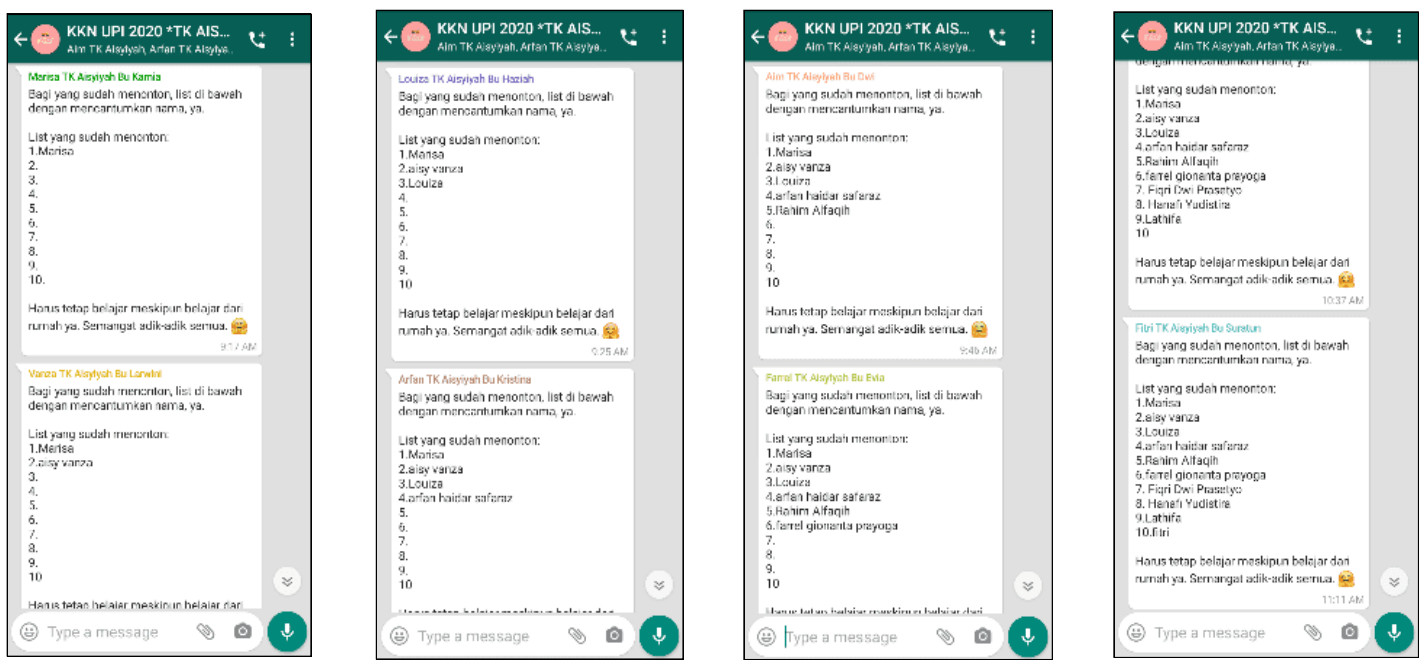

Gambar 4. Screen shoot respon orang tua siswa di WhatsApp Group 

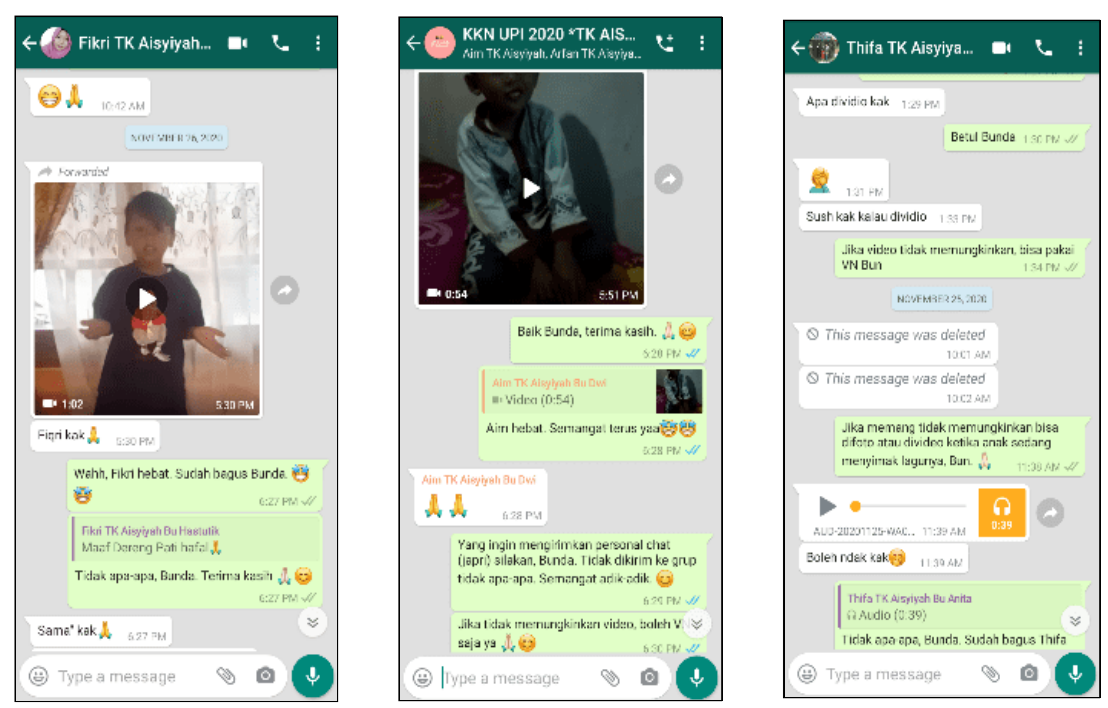

Gambar 5. Screen shoot pengumpulan hasil tugas siswa di WhatsApp Group yang dikirimkan oleh masing-masing orang tua siswa
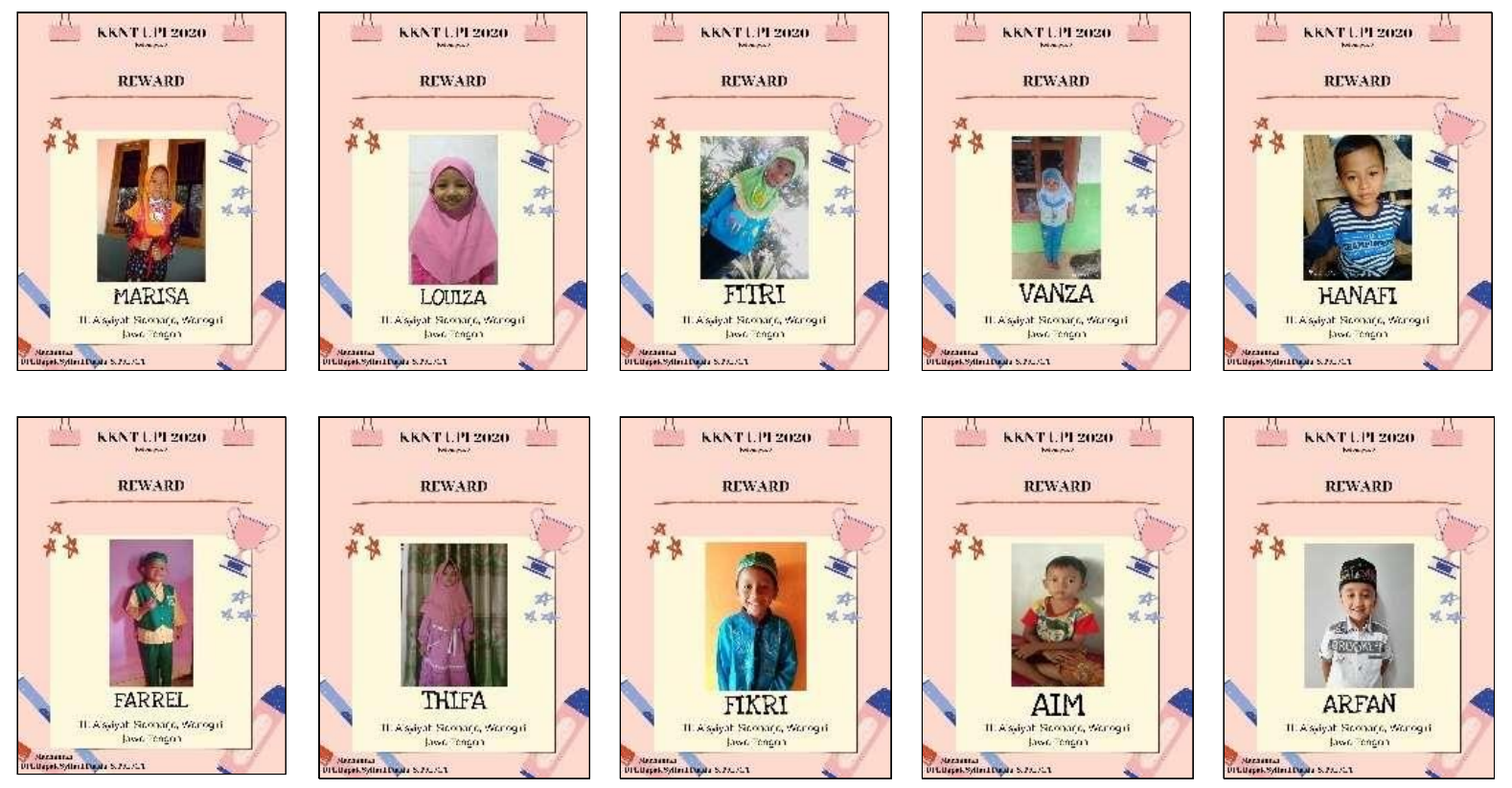

Gambar 6. Tampilan reward untuk siswa

\section{Pembahasan}

berdasarkan proses pelaksanaan dan evaluasi kegiatan, dapat diketahui bahwa kegiatan pembelajaran daring materi read aloud dengan menggunakan media vidio dapat berjalan dengan baik karena dukungan dari pihak sekolah dan orang tua siswa. Guru merasa terbantu dengan adanya dukungan pembelajaran daring, terutama penyediaan video pembelajaran yang mudah diakses oleh orang tua dan dipahami oleh siswa TIK. Kesadaran dan kepekaan orang tua dalam memahami anak tentang ketertarikan atau ketidaktertarikan dalam pembelajaran merupakan hal yang krusial bagi orang tua (Amariana, A., \& Ruhaena, 2012). Guru dapat membantu anak dalam mengembangkan minat anak usia dini terhadap minat baca melalui metode membaca nyaring (Sumitra \& Sumini, 2019). Berdasarkan hasil evaluasi, orang tua telah mengetahui bahwa anak tertarik terhadap read aloud video ditinjau dari kemampuan berbahasa anak, komunikasi verbal, dan kepercayaan diri anak. Namun ada 
orang tua yang tidak dapat mengikuti materi read aloud di WhatsApp Group sesuai jadwal karena rutinitas kerja yang tidak dapat ditinggalkan. Pembelajaran daring pada anak usia dini membutuhkan pendampingan penuh dari orang tua (atau orang dewasa) sehingga ada siswa yang tidak dapat mengikuti. Akan tetapi, melalui media pembelajaran daring read aloud video yang diunggah ke YouTube dapat diakses kapan dan di mana saja, sehingga anak tetap dapat menyimak materi yang diberikan dan didampingi oleh orang tua saat aktivitasnya selesai. Anak dapat mengirimkan tugas diluar jadwal belajar daring dan diterima dengan baik oleh pelaksana.

Media pembelajaran read aloud video telah dapat diterima dengan baik oleh siswa di TK Aisyiyah Sidoharjo berdasarkan antusiasme dan semangatnya dalam menyimak video tersebut serta keceriaannya dalam video hasil tugas di WhatsApp Group. Menurut orang tua siswa ketika diwawancarai secara personal, terdapat peningkatan keberanian (kepercayaan diri) dan kemampuan anak untuk berbicara setelah mendapatkan materi membaca nyaring melalui read aloud video yang disampaikan di WhatsApp Group. Pengetahuan dan aspek perkembangan bahasa dalam diri anak, kepercayaan diri dalam mengungkapkan pendapat, dan kecakapan berkomunikasi adalah hal yang urgen agar selalu dipantau oleh orang tua (Amariana, A., \& Ruhaena, 2012; Susilaningsih et al., 2018), dan juga guru selama proses belajar. Dengan read aloud video, pendampingan orang tua terhadap anak lebih ringan, karena cukup dengan menyimak Bersama anak, merekam anak saat menceritakan kembali isi buku dalam video, dan mengirimkan ke WhatsApp Group sebagai bentuk evaluasi. Orang tua kemudian menunjukkan reward (poster card) yang telah diberikan oleh pelaksana kepada anak untuk meningkatkan motivasi belajarnya.

Read aloud video dapat digunakan sebagai alternatif media pembelajaran daring untuk anak usia dini, khususnya di masa pandemi Covid-19. Kegiatan membaca nyaring sangat penting bagi anak usia dini karena dapat memberikan banyak manfaat dan dapat memberikan contoh kepada siswa tentang proses membaca yang positif, meningkatkan jumlah kosakata, memberikan pengetahuan baru, memperkenalkan ragam sastra, memberikan kesempatan kepada siswa untuk menyimak dan menggunakan daya imajinasinya (Dewi, 2017). Read aloud juga bertujuan agar siswa mampu memahami secara detail tentang isi suatu buku, memahami garis besar bacaan, membaca untuk menikmati karya sastra, mendapatkan informasi, dan mencari suatu istilah dalam buku (Sumriana, 2015). Read aloud mampu membangun kosakata, mengkondisikan otak, menciptakan pengetahuan umum, memberikan panutan yang baik, dan menanamkan keinginan untuk membaca (Gatot \& Doddyansyah, 2018). Semua proses pembelajaran pada kegiatan ini memanfaatkan platform gratis, yaitu WhatsApp, YouTube, Wondershare Filmora dan Canva.

Berdasarkan hasil yang diperoleh dikaitkan dengan literatur yang dikaji, maka dapat dinyatakan bahwa metode read aloud berbantuan video Youtube dapat menjadi metode belajar yang tepat saat pembelajaran daring bagi anak-anak usia dini. Read Aloud video membuat pembelajaran daring di TK Aisyiyah dapat lebih berwarna karena melibatkan media pembelajaran yang menarik dan baru bagi siswa ataupun orang tua, tidak hanya monoton berupa penugasan guru di WhatsApp saja.

\section{CONCLUSION}

Pelaksanaan kegiatan belajar read aloud menggunakan media vidio dilaksanakan di TK Aisyiyah dengan melibatkan 10 orang siswa. Proses pembelajaran dilakukan melalui 3 tahap pelaksanaan yang terdiri dari tahap persipan, pelaksanaan, dan tahap evalusi. Hasil dari pelaksanaan proses pembelajaran menunjukkan bahwa kegiatan belajar read aloud video yang berjalan dengan lancar mampu meningkatkan kemampuan anak dalam menyimak atau mendengar, melatih konsentrasi, menambah kosa kata, menstimulus imajinasi, merangsang 
kemampuan mengenal bahasa tulis, gambar, dan ilustrasi, serta merekatkan hubungan ibu dengan anak, video read aloud juga dapat dijadikan sebagai media yang dapat meningkatkan motivasi belajar anak.

\section{ACKNOWLEDGEMENT}

Terima kasih kepada LPPM UPI yang telah mendukung kegitan ini melalui program Kuliah Kerja Nyata Tematik Pencegahan dan Penanggulangan Dampak (KKNT-PPD) Covid19 Tahap II Tahun 2020. Terima kasih kepada TK Aisyiyah Sidoharjo, Wonogiri, Jawa Tengah yang telah memberikan izin dan kesempatan bagi pelaksana untuk melaksanakan KKNT di sekolah tersebut.

\section{REFERENCES}

Afandi, M., Chamalah, E., \& Wardani, O. P. (2013). Model dan Metode Pembelajaran di Sekolah. UNISSULA Press.

Amal, B. K. (2019). Pembelajaran Blended Learning Melalui Whatsapp Group (WAG). Prosiding Seminar Nasional Fakultas Ilmu Sosial, 700-702.

Amariana, A., \& Ruhaena, L. (2012). Keterlibatan Orang Tua dalam Perkembangan Literasi Anak Usia Dini. Universitas Muhammadiyah Surakarta.

Ayuni, D., Marini, T., Fauziddin, M., \& Pahrul, Y. (2020). Kesiapan Guru TK Menghadapi Pembelajaran Daring Masa Pandemi Covid-19. Jurnal Obsesi : Jurnal Pendidikan Anak Usia Dini, 5(1), 414. https://doi.org/10.31004/obsesi.v5i1.579.

Bhagaskara, A. E., Nur Afifah, E., \& Maulana Putra, E. (2021). Pembelajaran dalam Jaringan (DARING) Berbasis WhatsApp di SD Yapita. ZAHRA: Research and Tought Elementary School of Islam Journal, 2(1), 13-23. https://doi.org/10.37812/zahra.v2i1.183.

Dewi. (2017). Pengaruh Penggunaan Metode Reading Aloud terhadap Peningkatan Keterampilan Membaca Bahasa Jawa [Universitas Muhammadiyah Magelang]. http://eprintslib.ummgl.ac.id/489/1/12.0305.0182.

Dewi, W. A. (2020). Dampak Covid-19 terhadap Implementasi Pembelajaran Daring di Sekolah Dasar. Jurnal Ilmu Pendidikan Edukatif, 2(1), 55-61. https://edukatif.org/index.php/edukatif/article/ view/89.

Erik, B., \& Cahyati, N. (2020). Kegiatan Home Literacy Dalam Mengembangkan Kemampuan Awal Membaca Anak Usia Dini Di Masa Wfh. Jurnal Golden Age, 4(1), 160-166. https://e-journal.hamzanwadi.ac.id/index.php/jga/article/view/2219.

Fahyuni, E. F., \& Nurdyansyah. (2016). Inovasi Model Pembelajaran sesuai Kurikulum 2013. Nizamial Learning Center.

Gatot, M., \& Doddyansyah, M. R. (2018). Peningkatan Kemampuan Bahasa Anak melalui Metode Read Aloud. Jurnal Obor Penmas Pendidikan Luar Sekolah, 1(1), 56-66. http://dx.doi.org/10.32832 /oborpenmas.v1i1.1482.

Harjanty, R. (2019). Peningkatan Kemampuan Membaca Permulaan melalui Membaca Nyaring (Penelitian Tindakan di Kelompok B RA Perwanida Praya, Lombok Tengah). PAUD Lectura: Jurnal Pendidikan Anak Usia Dini, 3(01), 106-114. https://doi.org/10.31849/paud-lectura.v3i01.3353.

Hutami, M. S., \& Nugraheni, A. S. (2020). Metode Pembelajaran melalui Whatsapp Group sebagai Antisipasi Penyebaran Covid-19 pada AUD di TK ABA Kleco Kotagede. Jurnal Penelitian Dalam Bidang Pendidikan Anak Usia Dini, 9(1), 126-130. https://doi.org/10.26877/paudia.v9i1.6107.

Khusniyah, N. L., \& Hakim, L. (2019). Efektivitas Pembelajaran Berbasis Daring: Sebuah 
Bukti Pada Pembelajaran Bahasa Inggris. Jurnal Tatsqif, 17(1), 19-33. https://doi.org/10.20414/jtq.v17i1.667.

Kurnia, S., \& Fuada, S. (2021). Program Penguatan Pembelajaran Online di Paud RA Daarul Amiin Purwakarta pada Masa Pandemi Covid-19. Jurnal Pengabdian Kepada Masyarakat, 5(1), 101-112. https://doi.org/http://dx.doi.org/10.30734/jabdipamas.v5i1.1736.

Latipah, \& Fuada, S. (2021). Pelatihan Kinemaster bagi Guru TK Sekarwangi Cirebon untuk Meningkatkan Literasi dalam Pembuatan Video Pembelajaran Daring. Jurnal Pengabdian Kepada Masyarakat, 5(1), 101-112. https://doi.org/http://dx.doi.org/10.30734/j-abdipamas.v5i1.1696.

Lusiana, T. S., Briliany, N., Purdhani, L. T., Suryani, C., Nuraeni, S., Alfiyah, \& Maranatha, J. R. (2021). Edukasi Guru Dalam Pembuatan Infografis Media Pembelajaran Anak Usia 4-6 Tahun Menggunakan Aplikasi Canva Di TK Tunas Harapan. Indonesian Journal of Community Services in Engineering \& Education, 1(1), 8-14. https://ejournal.upi.edu/index.php/IJOCSEE/article/view/33193.

Majid, N. W. A., Abukahir, A., Alfathin, A., Ummah, A. H., \& Wardani, R. (2021). Optimalisasi Pembelajaran Efektif di Rumah Saat Pandemi Covid-19 kepada Warga Persyarikatan Muhammadiyah Kabupaten Purwakarta. Indonesian Journal of Community Services in Engineering \& Education, 1(1), 1-7.

Marli'ah, S., \& Apriliyana, F. A. (2021). Efektivitas Strategi Read Aloud dalam Mengenalkan Bahasa Inggris pada Anak Usia Dini. JCE (Journal of Childhood Education), $\quad 5(1), \quad 74-81 . \quad$ http://journalfai. unisla.ac.id/index.php/jce/article/download/496/422.

Nurhafizah, N. (2018). Pelatihan Pembuatan Media Pembelajaran Anak Usia Dini Menggunakan Bahan Sisa. Early Childhood: Jurnal Pendidikan, 2(2b), 44-53. https://doi.org/10.35568/earlychildhood. v2i2b.288.

Panjaitan, C. J., \& Hasanah, U. (2018). Meminimalisir Kesulitan Membaca dengan Metode Reading Aloud pada Siswa MIN 1 Langsa. Seminar Nasional Royal (SENAR), 547552. https://jurnal.stmikroyal. ac.id/index.php/senar/article/view/238.

Priyantini, L. D. E., \& Yusuf, A. (2020). The Influence of Literacy and Read Aloud Activities on the Early Childhood Education Students' Receptive Language Skills. Journal of Primary Education, 9(3), 295-302. https://doi.org/10.15294/jpe.v9i3.39216.

Putria, H., Maula, L. H., \& Uswatun, D. A. (2020). Analisis Proses Pembelajaran dalam Jaringan (DARING) Masa Pandemi Covid- 19 Pada Guru Sekolah Dasar. Jurnal Basicedu, 4(4), 861-870. https://doi.org/10.31004/basicedu.v4i4.460.

Riadil, I. G., Nuraeni, M., \& Prakoso, Y. M. (2020). Persepsi Guru PAUD terhadap Sistem Pembelajaran Daring melalui Whatsapp di Masa Pandemi Covid-19. PAUDIA: Jurnal Penelitian Dalam Bidang Pendidikan Anak Usia Dini, 9(2), 89-110. https://doi.org/10.26877/paudia.v9i1.6574.

Sahidillah, M. W., \& Miftahurrisqi, P. (2019). Whatsapp sebagai Media Literasi Digital Siswa. Jurnal VARIDIKA, 1(1), 52-57. https://doi.org/10.23917/varidika.v1i1.8904.

Salam, R. (2021). Perubahan dan Inovasi Pelayanan Publik di Era New Normal. Journal of Public Administration and Government, 3(1), 28-36. https://doi.org/10.22487/jpag.v3i1.138.

Sauri, F. S. (2019). Perancangan Storyboard Dalam Film Animasi 3d " Sons Of Pandawa " Storyboard Design In 3D Animation Film " Sons Of Pandawa " Keywords: Storyboard, Adaptation, Puppet Figure , 3D Animation Film. 6(2), 1672-1680.

Sumitra, A., \& Sumini, N. (2019). Peran Guru Dalam Mengembangkan Kemampuan Minat Baca Anak Usia Dini Melalui Metode Read Aloud. Jurnal Ilmiah Potensia, 4(2), 
115-120. https://doi.org/ 10.33369/jip.4.2.115-120.

Sumriana. (2015). Peningkatan Kemampuan Membaca Nyaring dengan Menggunakan Metode Latihan Siswa Kelas III SDN 5 Kayumalue Ngapa Kecamatan Palu Utara. Jurnal Bahasantodea, $3(2)$, $50-58$. http://jurnal.untad.ac.id/jurnal/index.php/Bahasantodea/article/view/6312.

Suradika, A., Gunadi, A. A., \& Jaya, S. A. (2020). Penggunaan Youtube sebagai Media Pembelajaran Jarak Jauh pada Kelas III Sekolah Dasar Islam An - Nizomiyah. Jurnal Pengabdian Masyarakat Fakultas Ilmu Pendidikan, 1(1), 1-10. https://jurnal.umj.ac.id/index.php/semnaslit/article/view/8781.

Susilaningsih, S., Abbas, N., \& Nurharini, A. (2018). Strategi Interactive Read Alouds Dalamoptimalisasi Keterampilan Pemahaman Dongeng Anak Di Sdn 01 Tawangmas Semarang. Jurnal Penelitian Pendidikan, 35(1), 77-82. https://doi.org/10.15294/jpp.v35i1.15093.

Suyadi. (2015). Teori Pembelajaran Anak Usia Dini Dalam Kajian Neurosains. Remaja Rosdakarya.

Taruno, H. T., Widyastuti, S., Zamania, A. N., \& Mulyono, J. (2020). Hasil Survei Sosial Demografi Dampak Covid-19 Provinsi Jawa Tengah 2020. Badan Pusat Statistik Provinsi Jawa Tengah.

Yumnah, S. (2017). Membudayakan Membaca dengan Metode Read Aloud. Jurnal Studi Islam, 12(1),

84-90. http://ejournal.kopertais4.or.id/tapalkuda/index.php/pwahana/article/view/2907. 